\title{
FUNCTIONING OF ADULTS FROM SINGLE-PARENT FAMILIES IN A FAMILY AND PROFESSIONAL ENVIRONMENT
}

\author{
MARIOLA WOJCIECHOWSKA, MARLENA MiCHALSKA
}

\begin{abstract}
The modern world puts great demands on people when it comes to understanding its purpose and meaning, which undoubtedly changes the lives of individuals and social groups. People are particularly concerned about the possibility of freeing themselves from imposed group ties, enjoying the rights of a citizen and a member of a community, and the way in which freedom is exercised without restrictions. What has so far been a well-established basis for human activity and the maintenance of the existing order is now losing its importance, and is being replaced by new life opportunities. The authority of traditional social structures such as the social class, local community or family has declined. Normative and axiological systems, and consequently the quality of functioning of the contemporary family, its structure, scope of performed duties and relations within a family, have also undergone transformations. It is becoming increasingly common for adults who form the main axis of the family to decide on a divorce. This is not conducive to the optimum development of children, as they lose the sense of security, trust in adults, fail to fulfil their own lives and even doubt about the existence of true unselfish love. Parents' divorce decisions often result in emotional and motivational disorders which are manifested by difficulties in establishing social contacts, building profound relationships and coping with difficult situations. The paper shows the results of exploratory research on how adults brought up in divorced single-parent families can function in the social and professional environment. The research employs the diagnostic survey method using the auditorium questionnaire and the "100 Sentences - 100 Opinions" tool by Mirosław J. Szymański. The results of the research clearly show that adults brought up in single-parent families are involved very differently in social and professional life. They build their short- and long-term professional and personal goals in distinct ways. Personal and social characteristics of the respondents are the factors determining the observed activity. The research results are in line with the relevant literature and prove the impact of growing up in a single-parent family on children's activity in adult life.
\end{abstract}

Keywords: single-parent family, divorce, social and professional activity.

\section{INTRODUCTION}

Dynamic transformations of the modern world cause changes in almost every aspect of our lives and also affect the functioning of a family. The rules of the family life that have been established and implemented in the past are losing their importance, and new standards of living in the family environment are being introduced in their place. However, it must be assumed that the family is still a fundamental social group which should provide a valuable environment, a unique community, and fulfil many functions in everyone's life [7, p. 25; 26, p. 45; 24, p. 303; 12, p. 12; 34, p. 234], be a place of 
socialisation, care, procreation and satisfaction of basic needs. Fulfilling the family's responsibilities properly enables children to develop in every sphere and to undertake efforts to build their own system of values [30]. Children seek to imitate their parents, which is why it is so important - even fundamental - to have a proper family relationship. From the multitude of studies on the importance of the family as an educational environment, the viewpoint of Zbigniew Tyszka should be distinguished. He emphasises that the family [...] lies at the heart of society, builds it and influences its development. At the same time, it is a so-called reference group with which people consciously and strongly identify as members and representatives of the group, discovering, taking over and co-creating the views, attitudes, customs and patterns of conduct cultivated in it" $[29$, p. 6]. As a small primary group, a family complies with the rules of natural law, customs and cultural context [26, p. 300], and creates the conditions for people to adapt actively during their formative years [14, p. 49].

Numerous authors argue that the family should be a source of unconditional love, based on selfless deeds, mutual care and expression of interest towards all its members. In the past, one of the basic elements determining the proper functioning of the family was appreciation and respect for authority, the sense of belonging, awareness of one's own position in a community and of one's roles. It should be noted with concern that modern families are exposed to many disruptions and crises regarding these issues, which often result in their break-up. The changes taking place outside and inside the family may lead to conflicts between members and even complications in the implementation of certain roles. There is a noticeable fragility of modern marriages which - when confronted with problems - do not try to see the real source of intra-family conflicts, but decide to part [16, p. 8]. The break-up of a family involves many negative experiences for each party, but due to its sensitivity and vulnerability the youngest members of the family are the ones who suffer most. A disruption of the sense of security and the rupture experienced by young people are certainly extremely difficult conditions for them. A divorce of parents entails the development of neurotic qualities in children that accompany them throughout their lives. As adults, people from single-parent families will often display fear of other people, accompanied by a sense of non-fulfilment of their own lives and a doubt about the existence of true unselfish love.

There are many reasons why families become incomplete, such as a conscious decision to raise a child alone, the death of one of the parents, the long absence of one of them due to the nature of their work, or the need to be isolated due to chronic illness or sentence, separation or divorce. Due to the subject matter addressed in this paper, the main focus of consideration will be on single-parent families which have become such due to parents' divorce. Single-parent families are the ones without one parent [18, p. 37; 21, p. 41], and the upbringing issues are arranged along the model: child - mother, child - father [21, p. 41]. Such conditions obstruct the creation of a good space and emotional climate for the family, which may disrupt the psychophysical, spiritual and social development of children and weaken their sense of importance [22, p. 88]. Dysfunctional relations between parents and their child are conducive to harmful socialisation and improper formation of personality. Hostility and fear experienced by a child trigger aggression and even depression symptoms [8, p. 84], it is possible to notice increased levels of excitability and nervous tension. Emotional and motivational disorders lead to difficulties in establishing appropriate social contacts, engaging in interactions, and there are also extreme behaviours: a desire for closeness or indifference and emotional coldness towards others. The absence of a role model hinders personal development and gender identification, which results in the impairment of social feelings that are characterised by less sensitivity to other people. Also, young people may misinterpret the behaviour of others, assuming in advance that they are overloaded with aggression and a desire to do harm.

The role of relationships and emotional ties with parents is invaluable. This is because they form the foundations on which our whole life is based; they are a model and a signpost which is reproduced by individuals in other environments. They also provide an opportunity to get to know oneself, understand one's feelings, needs and expectations towards the world, life and people. These arguments have been confirmed in numerous studies. They suggest that people displaying social maladjustment come from families with many deficits, including lack of emotional stability, harmony and positive relations between spouses [35, p. 50-51]. 


\subsection{DYNAMICS OF DIVORCE AND SEPARATION AND THEIR CAUSES}

It is difficult to present a complete list of reasons, including legal ones, for divorce of parents, as well as to distinguish between the significance of the reasons indicated. One can only indicate the type and nature of the factors examined. Among the determinants of the complete and permanent disintegration of married life there are: culpable factors (all kinds of addictions correlated with deterioration of quality of life, inadequate treatment of relatives, disrespect for the spouse, concealment of illness, failure to fulfil one's role in the duties of the spouse and the household, cheating), nonculpable (different systems of values, impotence, mental and physical illnesses), culpable and nonculpable (differences in worldviews, infertility, significant age difference between partners, inappropriate attitude of the spouse's family, defects in declaration of will) [24, p. 36].

\begin{tabular}{|c|c|c|c|c|c|c|c|c|}
\hline Specification & 1950 & 1960 & 1970 & 1980 & 1990 & 2000 & 2010 & 2018 \\
\hline Town & 8.6 & 12.4 & 29.6 & 33.9 & 34.3 & 36 & 47.4 & 45.2 \\
\hline Village & 2.4 & 2.4 & 4.9 & 5.9 & 7.3 & 6.7 & 13.4 & 16.6 \\
\hline Total [thousands] & 11 & 14.8 & 34.6 & 40.3 & 42.4 & 42.8 & 61.3 & 62.8 \\
\hline
\end{tabular}

Tab. 1. Dynamics of divorces in the period of 1950-2018 (source: Demographic situation in Poland up to 2018 Creation and disintegration of families, Warsaw 2019, p. 89, www.stat.gov.pl).

\begin{tabular}{|c|c|c|c|c|}
\hline Year & 2000 & 2010 & 2018 & 2019 \\
\hline Per 10000 people & 11.1 & 15.9 & 16.4 & 17.0 \\
\hline
\end{tabular}

Tab. 2. Data on the number of divorces in Poland (source: GUS-Central Statistics Office, Demographic Yearbook, Warsaw 2020, p. 230).

\begin{tabular}{|c|c|c|c|}
\hline Year & 2016 & 2017 & 2018 \\
\hline Ratio [thousands] & 3.8 & 3.5 & 3 \\
\hline
\end{tabular}

Tab. 3. Data on separation in the period of 2016-2018 (source: I. Kacprzak, Poles prefer divorces to repairing relationships - www.spoleczenstwo.pl).

\begin{tabular}{|c|c|c|c|c|}
\hline Year & 2010 & 2015 & 2018 & 2019 \\
\hline Ratio [thousands] & 2.8 & 1.7 & 1.3 & 1.2 \\
\hline
\end{tabular}

Tab. 4. Data on separation in the period of 2010-2019 (source: GUS-Central Statistics Office, Demographic Situation in Poland up to 2019; Foreign Migrations of People in 2009-2019, Warsaw 2020, p. 204).

According to the data on the reasons for divorces in Poland in 2017, one of the main causes of the relationship's disintegration was the incompatibility of characters $(40.0 \%)$. Every fifth respondent reported that finding out the truth about partner's cheating resulted in a decision to divorce. The third position at the list of reasons was occupied by the addictions. The least frequent reason for divorce was long absence of a partner $(2.0 \%)$ [17, p. 14]. On the other hand, in a survey conducted in 2019, almost all respondents (95.0\%) pointed to the aggression of one of the family members as the reason for the family break-up, and nearly $50.0 \%$ pointed to addictions [23, p. 5]. The data presented suggest an increasing number of divorces over the last eight decades (Table 1, Table 2). In 1950, the number of divorces reached a little over 10,000, whereas 20 years later almost 35,000 were granted annually, and in 2018 over 62,000 marriages divorced. Since 1950, marriages have been splitting much more often in towns than in villages. There has also been a decline in the number of separation requests (Table 3, Table 4). In the past (1970s and 1980s), people were convinced that the divorce phenomenon was only a temporary crisis they would quickly cope with, and children who witnessed the break-up of their own family 
would not be affected by it to such an extent that it would determine their later, adult life. However, these assumptions were not confirmed by actual experiences. Painful memories from childhood are felt throughout life, these wounds never heal [15, p. 158]. The range of undesirable behaviours and attitudes from childhood, linked to functioning in an incomplete family due to parents' divorce, is very broad. Particularly noticeable are the distortions related to the ability to trust other people, the feeling of stability and security, the ability to love oneself and others, the ability of self-fulfilment, the weakening of the parent's authority [2, p. 23]. Also, the characteristics of people from single-parent families are also indicated. These include: feeling ashamed of showing one's own weaknesses, deeprooted anger (sometimes targeted), fear of thinking about the past, desire to achieve control over every sphere of life/perfectionism, feeling guilty about one's own imperfections, fear of intimacy [2, p. 41]. There is a strong desire to erase all negative childhood recollections related to parents' divorce from memory [2, p. 54-57].

On average, children need 5-7 times longer than adults to be able to accept the breakdown of their families. Sadness and loneliness are the most prominent feelings that are associated with childhood. Moreover, people from divorced, single-parent families, are twice as likely to experience relationship breakdowns than people who grew up in a full family [20, p. 120]. Functioning in a broken family distorts the image of oneself, with the desire to be perfect on one hand, and on the other - the feeling of being a person unworthy of happiness and love. The unrestrained desire to control every aspect of life and constant self-dissatisfaction become severe (successes "are a brief joy", while emptiness and dissatisfaction persist all the time) [2, p. 64-65]. The studies clearly indicate that divorce of parents has an impact on many areas of a young person's life. It is important to underline the fact that the break-up of parents' relationship has determined how adults from single-parent families perceive being in a relationship and what form their own marriage takes [1, p. 181].

\section{OWN STUDIES - AsSUMPTIONS}

Based on the above considerations, a research project has been drawn up to analyse how adults from divorced single-parent families can function in the social and professional environment. The primary objective of the research was to analyse the functioning of the respondents in the specific areas mentioned. The obtained results will be used to formulate guidelines and recommendations in the construction of educational activities for children and adolescents operating in divorced single-parent families. This will certainly be a practical application of research results. The main problem of the research was the question of the scope of functioning in the local, family and professional environments of adults from single-parent families, and the conditions of the investigated scope.

The research was exploratory, and thus no hypotheses have been put forward. They were only formulated in an operational manner as a result of recognising the distribution of variables. The study employed the correlation model, i.e., the explained, explanatory and contextual variables have been distinguished. The explained variable were respondents' declarations concerning their social, family and professional functioning (an empirical indicator was used for this variable). The explanatory variables were the individual variables and social characteristics that are considered important in this type of research (gender, age, education, place of residence).

The study employed the diagnostic survey method, which was carried out using an auditorium survey and the "100 Sentences - 100 Opinions" questionnaire by Mirosław J. Szymański. This tool consisted of 100 different statements, and the respondents were to give their opinions on them. The scope of opinions concerned 10 groups of values: pro-social, cultural, civic, affiliate, pleasure, material, educational, family, power and work. In order to verify whether the respondents demonstrate a stable attitude to the indicated values, each group contains seven approval sentences and three denials of particular values. The questionnaire contained a 5-point scale (from -2 to +2 ), to each of the hundred sentences. A fragment of M.J. Szymański's tool relating to pro-social values was analysed for the purpose of own research [30, p. 92]. All empirical materials have been compiled statistically using the SPSS statistical software package. The analysis was based on the absolute and percentage distributions 
of the variables used in the study, as well as on mean measures and standard deviation. The results obtained were compared between the groups by means of the correlation method.

\subsection{ChARACTERISTICS OF STUDY AREA AND SAMPLE}

The study was conducted on the Internet, by means of online surveys on one of the social networking sites. The questionnaires completed by the respondents were automatically recorded in the database. A link to the research was provided in four groups of the portal. The basic assumptions of the functioning of the groups selected for research is that they support each other in difficult moments in life. People active in community forums support one another emotionally in overcoming everyday difficulties, inspire one another and create favourable conditions for discussion on current issues.

The research sample consisted of 208 respondents, of whom more than half were women (54.5\%). The percentage of men in the study was somewhat lower $(45.5 \%)$. The overwhelming majority of respondents declared the age bracket of 15-25 years (43.3\%). The respondents between 26-35 years of age were slightly less numerous. A marginal number of respondents were over 45 years old (3.7\%). In each of the analysed age categories, the gender ratio was similar except for the youngest respondents, which was dominated by women. The analysis of respondents' marital status indicated a high proportion of unmarried persons (43.3\%). Nearly one-third live in informal relationships. The data show an equal share of those living in formal relationships and those divorced $(10.5 \%$ in both groups respectively). The gender ratio in those categories was similar.

In terms of education, the predominating group are the respondents with secondary education $(37.5 \%)$. One in three people declares having a master's degree. The respondents with primary education are the least numerous in the survey $(1.2 \%)$. The majority of women hold a master's degree (23.1\%). Men most often declare to have completed secondary education (43.8\%). More than a half of the respondents (53.6\%) live in cities with a population of over 200,000, and one in ten respondents indicated a village as their place of residence. As regards the education category, a comparable gender share in respondents was observed.

\subsection{RESEARCH RESULTS}

The research has produced a wide range of data. The ones that directly relate to the title of the work have been selected for the purpose of this article. In the first place, attention was focused on the respondents' plans for their own future. The data indicate that the most common ambition was personal and professional development (13.9\%) and establishing own family (12.5\%). The obtained indicators clearly show that the surveyed respondents fit in with the general trends in young people's planning of their lives. It should be acknowledged with satisfaction that the respondents thus express a proper understanding of the dynamics of change in the contemporary world in all its scopes, and that it is necessary to follow them. The development of personal sphere is connected with acquiring new professional competences, including self-creation, which in the long run makes it possible to consider one's own life as interesting and rewarding. According to the respondents, an important component of their own future is establishing a family, which, on one hand, corresponds to the majority of young people's choices, as evidenced by the highest appreciation for the value of family safety, as stated in M. Wojciechowska's research [32, p. 152], but it is also an expression of a longing for the sense of security and support from those closest ones [19, p. 169-171]. Other categories, i.e., spiritual development and no idea for life, were selected by a minor number of respondents $(1.1 \%)$.

It is worth emphasising at this point that respondents' gender did not differentiate their opinions. Although women expressed the desire to achieve a high material status much less frequently than men, the choices of other response categories were generally very similar in both groups. As regards education, investing in own personal and professional development was most often declared by the respondents with secondary education and above (close to $22.0 \%$ ). The respondents whose education ended with the completion of primary or vocational school were least likely to consider personal 
development as an action they would like to take in the future. This group also includes people who find it difficult to build their own visions of short- or long-term actions.

Some interesting findings emerge from the analysis of the correlation between the plans for the future and respondent's age. The category of personal development was indicated by the respondents irrespective of the age bracket represented. On the other hand, declarations about establishing a family were mostly made by people aged 15-25 (89.7\%) and 26-35 (99.0\%). The remaining age brackets include people who mostly already have a stable family situation (including the educational one), which is why they choose these categories less frequently. A similar situation occurs with regard to the intention to complete school as a plan for the future, indicated by the respondents between 15-25 years (68.4\%) and $26-35$ years $(7.2 \%)$. For the reasons mentioned above, the older respondents only marginally referred to that category. At this point, it is worth referring to the plans for the future of young people a few decades ago, compared with the intentions currently expressed. Young people still indicate their aspirations to have a family, to gain an education and make a professional career [15, p. 77].

\section{Professional Activity}

Functioning in the professional space was evaluated on the basis of, among others, the relation of the respondents to the entrusted professional tasks. The declarations obtained reveal a high level of commitment and great care in the performance of professional duties. This category was selected the most frequently (15.3\%). The attitude towards overcoming obstacles on the way to the task implementation $(15.7 \%)$ and expecting recognition from the employer as an important aspect related to professional activity (14.8\%) were also emphasised. These issues were stressed by all respondents. However, a certain difference has been observed in the choice of preferences as regards forms of work. Women were more inclined to work in a team (59.6\%), while men preferred an individual work style $(70.2 \%)\left(\mathrm{r}_{\mathrm{c}}=0,445\right)$. Discrepancies in declarations are also noticeable when considering the education category $\left(\mathrm{r}_{\mathrm{c}}=0,423\right)$. The respondents with higher education pointed to independent work and, moreover, to great difficulties in coping with failure $(95.0 \%)$ while not being appreciated by their work superiors $(87.5 \%)$. These people impose demands upon themselves which are quite high but also difficult to meet; they want to have full control over the course of current events, they experience fear of change, which to some extent corresponds to the assumption that this is the result of certain childhood experiences [33, p. 9]. People from single-parent families demonstrate the need to be noticed and appreciated. A persistent confirmation of one's self-esteem based on the opinions of others can be so strong that people who feel it are willing to do a great deal to win the appreciation of those around them. J. Bragiel has found out that the adults, who experienced disintegration of their parents' relationship as adolescents, demonstrate disruption of every sphere of life to a smaller or larger extent. The quoted author emphasised that no respondent stated that parents' divorce had no impact whatsoever upon their current life. Moreover, the conflicts between parents in the past are very often reflected in respondents' professional work [1, p. 181]. Different attitudes to professional responsibilities depending on gender may result from the fact that, in general, women are less likely to compete for promotion, are less conflictual, which makes cooperation with them easier; they appreciate positive contacts with other employees and are more communicative [6, p. 3]. Therefore, the observed link between the preferred mode of work and gender may be a consequence of the socialisation process, but also of the differences between men and women in this respect.

The ability to adapt to new situations has been deployed in the dimension of professional activity. Nearly half of the respondents stated that they have no difficulty adapting to new situations. This observation can be explained by the assertion that while people who witness conflicts between parents in childhood are deprived of a sense of security and stability, it is not always true that parents' divorce only has a negative impact on children. In terms of adaptation to situations not experienced thus far, women (31.8\%) demonstrated a higher level than men. The latter expressed the opinion that their adaptation to new situations is bad and very bad $(14.6 \%)\left(\mathrm{r}_{\mathrm{c}}=0,474\right)$. It is noteworthy that a fairly large number of the respondents do not have a clear opinion on this issue $(17.3 \%)$. The differences in adapting to new situations outlined above correspond to general trends indicating that women adapt 
faster than men to new situations and rules, and that adapting to changing conditions is not an obstacle to them. Women are also characterised by a greater mobilisation in action [9, p. 170-171].

In the category of education, it should be stated that the higher level of respondents' education corresponds to their better adaptation to new situations. This confirms the link between education and quality of life [25, p. 509]. It should be assumed that people with higher education are potentially more aware, and that the broad knowledge they have accumulated enables them to combat their own weaknesses and limitations more effectively.

The data explicitly prove that middle-aged people perform much better (well and very well) in new situations: $36-45$ years of age $(6.7 \%), 46-55$ years $(1.9 \%), 56$ and more $(1.0 \%)\left(r_{c}=0,341\right)$. The respondents who estimated their own adaptation at a much lower level were most often in the 15-25 age group (15.4\%), i.e., in adolescence period, when new situations can be seen as particularly dangerous. On the other hand, N. Ogińska-Bulik and Z. Juczyński claim that the older people - more than 40 years of age are characterised by greater perseverance, the ability to mobilise in stressful circumstances and greater tolerance of negative emotions [11, p. 50], which has been confirmed in the results obtained.

\section{SOCIAL ACTIVITY}

As regards the social activity of the respondents, it is noted with concern that nearly half of them $(45.2 \%)$ do not take any actions to the benefit of others. Among the respondents, only one in five women $(20.4 \%)$ declared to have participated in voluntary work, and only one in ten men $(9.7 \%)$ indicated that they were involved in a non-profit organisation. A similar situation applies to charity actions where women are also more involved. The least frequent activities declared by the respondent were the work in organisations and running associations (3.9\%), which is due to the fact that such activities are rather time-consuming. In general, as also confirmed by the research of other authors, women have declared more often that they engage in social work (unpaid and voluntary) and considered it appropriate to show solidarity with those in need [10, p. 133]. They are more oriented toward pro-social activities and they maintain contacts with other people [32, p. 102].

More social activities are carried out by respondents with master's degree and higher vocational education $\left(47.1 \%\right.$ in total) $\left(\mathrm{r}_{\mathrm{c}}=0,437\right)$, who declared more often their participation in charity activities for the benefit of others. By contrast, the respondents with vocational and primary education perform these activities only sporadically (2.0\%). It should therefore be reaffirmed, in line with other researchers, that the social position measured by the education declared by the respondents determines the level of involvement in civic life [3, p. 166].

Participation of respondents in social activities for the benefit of those in need is most often found in the following age brackets: $15-25$ years (43.3\%) and 26-35 years (37.4\%). Every fifth respondent aged $36-45$ years $(19.3 \%)$ has declared to carry out activities for non-profit organisations. There is a significant difference in activities addressed to people in need, taking into account respondents' age $\left(\mathrm{r}_{\mathrm{c}}=0,256\right)$. Since the respondents come from single-parent families, where relations with relatives are often abnormal, there may be a strong desire, especially in younger respondents, to create social, nonfamily or neighbourly ties associated with supporting others. A. Domaradzka claims that it provides an opportunity to distance oneself from one's own difficulties and problems [3, p. 166].

To complete the considerations on respondents' social activities, an analysis of their recognition of pro-social values has been conducted. In order to do this, the study employed the previously described "100 Sentences - 100 Opinions" tool by Mirosław J. Szymański. The data indicate that the respondents clearly agreed with the statement that actions for the benefit of others are the source of fulfilment, satisfaction. The following opinion was ranked quite high among the ten opinions representing this group of values: "Commitment to others increases the satisfaction of own life" ( $\mathrm{M}=1.089, \mathrm{~s}=0.837)$, which was highly approved by both women $(\mathrm{M}=1.072$, s=0.873) and men $(\mathrm{M}=0.786, \mathrm{~s}=1.251)$. Recognising values in support activities addressed to people in need proves the ability to see a variety of good deeds and the orientation towards the assumption that selflessness and altruism can be a potential source of happiness for aid workers. A standard of reciprocity may be a motive for pro-social behaviour. People who declare their willingness to help are guided by the conviction that such attitude increases their 
chances of receiving support in the future when they find themselves in a difficult situation. They also feel the need to maintain a positive self-image [27, p. 134].

High approval for the above-mentioned thesis is distorted by the opinions on subsequent statements: "Everyone should strive to achieve their own goals, tending the needs of others is just an unnecessary waste of time" ( $\mathrm{M}=0.774, \mathrm{~s}=1.043)$ and "In order to achieve success in life, one must be guided solely by one's own interests." ( $(\mathrm{M}=0.331, \mathrm{~s}=1.206)$. Respondents' assessment of the quoted views demonstrates inconsistency of their opinions. The results of the research are coherent with the research by M. Wojciechowska, where respondents have shown a willingness to help people with disabilities, while at the same time accepting the statement that focusing attention on the needs of others losing time spent on activities that are considered uninteresting. The respondents may have assumed that it is pointless to help others if they themselves feel a deficit of support and assistance [30;31].

This result raises questions, and explaining it causes some difficulties. On one hand, young people see many examples of social charity and selfless help, as well as disapproval of selfish, calculated and greedy behaviour. Assisting those in need has recently become quite popular. Many people share information about their charitable activities through the media. On the other hand, young people are guided by the privilege of being able to establish their own goals and focus on their individual needs. The reasons for inconsistency of the responses may also be wishful thinking as well as creating a vision in which people see themselves as good human beings.

\section{RESEARCH CONCLUSIONS}

The sources of crisis of a contemporary family should be found in the phenomena that are characteristic of modernity, including: philosophy of individualism, differentiation, rationality or expansiveness. We live in the conditions that allow for creating our own vision of the world, strengthening pluralism of views and opinions, but also intensification of moral relativism and indifferentism. Freedom of choice is the value appreciated by modern people. Being in an unhappy relationship is no longer seen as a lifelong necessity. The growth in women's educational and professional aspirations in recent years has strengthened their social position and made them more independent. The increasing social tolerance for divorce is an additional factor determining the rise in the number of parting marriages. The possibility of separation and starting a new life is perceived as an opportunity to build a more satisfying life and to feel happiness. However, adults' decisions do not only concern them, but they are also a serious challenge for younger family members. Divorce is a source of stress, a highly emotionally intense event for all family members. The effects of the divorce decision taken by parents are most often a serious complication for the children, experienced "here and now" and during the subsequent stages of their lives. The feeling of helplessness, fear, loss of security all these have consequences for the quality of life of younger family members. Adults who grew up in divorced families display emotional withdrawal, distrust, low self-esteem, an attitude of perfectionism, a desire to be noticed and a need to be in control [20, p. 118, 120]. Enabling an effective elimination of the trauma associated with parents' divorce is still an ongoing issue. It should be recalled, however, that the aspects which differentiate the effectiveness of assistance are both individual personality traits and the current family situation, which consists, among other things, of the quality of relations between individual family members and environmental resources available to the community.

It should be stated in the research findings that the respondents' involvement in social and professional life varies considerably. This is due to the multitude of issues that arise as a result of parents' divorce. With regard to the examined scopes presented in this paper, some differences are found in the categories of respondents' age, gender and education. However, it is to be welcomed that, regardless of gender, respondents wish to continue to develop, and have also expressed a desire to start their own family. In spite of the continuing tendency to treat their own goals as the primary ones, and the weakening position of the family community, respondents still deem the family community an important part of life. 
The link between the respondents' education and social and professional functioning is also worth mentioning. It is clear that having a broad knowledge and competences determines significantly both further plans for one's own future and creates an important source of inspiration and choices. Educated people have a better basis, which they consciously use to work on their own limitations and weaknesses. They also declare undertaking pro-social activities, vividly emphasizing that providing help is a source of positive emotions (joy and pride).

It should also be noted with satisfaction that the range of activities undertaken for the benefit of others and the level of social competence increases with respondents' age and the corresponding greater involvement in building the quality of one's own life. A detailed analysis of the data suggests that the people surveyed exhibit characteristics of a perfectionist attitude. The need for constant control of the situation and environment, high demands on one's own actions and the desire to be perfect can be found in the respondents' statements.

Knowledge of the range of social and professional activities of adults from single-parent families should become valuable information for those who empower the social environment of children going through their parents' divorce. Teachers and educators should also play an important role. Careful selection of appropriate supporting and protective measures can significantly alleviate difficult current experiences, build defensive mechanisms and teach how to cope with stress. It is also advisable to assist in the development of individual resources, in activating young people to seek worthy life goals.

\section{REFERENCES}

[1] Bragiel J. Skutki rozwodu rodziców - z perspektywy dorosłego życia [The Effects of Parents' Divorce Adult Life Perspective]. Rocznik Socjologii Rodziny, XI (1999), 181. (in Polish)

[2] Conawy J. Doroste dzieci rozwiedzionych rodziców [Adult Children of Divorced Parents]. Wydawnictwo Logos, Warszawa, 1997. (in Polish)

[3] Domaradzka A. Aktywni inaczej? Przyczyny (nie)aktywności społecznej Polaków, Społeczeństwo w czasach zmiany [Active Otherwise? Reasons for Social (in)activity of Poles, Society in Times of Change]. (Eds.) Radkiewicz P., Siemieńska R. Wydawnictwo Scholar, Warszawa, 2010. (in Polish)

[4] GUS-Central Statistics Office, Demographic Yearbook. Warsaw, 2020. (in Polish)

[5] GUS-Central Statistics Office, Demographic Situation in Poland up to 2019; Foreign Migrations of People in 2009-2019. Warsaw, 2020. (in Polish)

[6] Kotlarska - Michalska A. Społeczne Role kobiet [Social Roles of Women]. Edukacja Humanistyczna, 1 (2011), 3. (in Polish)

[7] Krzesińska-Żach B. Pedagogika rodziny [Pedagogy of a Family]. Wydawnictwo Trans Humana, Białystok, 2007. (in Polish)

[8] Kuźniewska Z. Wpływ rozwodu rodziców na psychikę dziecka [The Impact of Parents' Divorce Upon Child's Psyche]. Cywilizacja i Polityka, 17 (2019), 84. (in Polish)

[9] Lisowska E. Równouprawnienie kobiet i mężczyzn w społeczeństwie [Equality of Women and Men in Society]. Wydawnictwo Szkoły Głównej Handlowej, Warszawa, 2008, 170-171. (in Polish)

[10] Masłyk T. Aktywni obywatele - analiza porównawcza osób działających w organizacjach trzeciego sektora w Polsce [Active Citizens - Comparative Analysis of People Active in Third Sector Organisations in Poland]. Polityka i Społeczeństwo, 2 (2017), 133. (in Polish)

[11] Ogińska-Bulik N., Juczyński Z. Skala pomiaru prężności - SPP-25 [Resilience Assessment Scale - RAS25]. Nowiny Psychologiczne, 3 (2008), 50. (in Polish)

[12] Ostrowska K. Podstawowe funkcje rodziny [Fundamental Functions of a Family]. In: K. Ostrowska, M. Ryś (Ed.) Przygotowanie do życia w rodzinie [Getting Ready for Family Life]. Cz. 1, Wydawnictwo ADAM, Warszawa, 1997. (in Polish)

[13] Pawlina K. Nowe pokolenie Polaków a kondycja rodziny [The New Generation of Poles and Condition of a Family]. Studia Salvatoriana Polanica, 5 (2011), 77. (in Polish) 
[14] Pieter J. Poznawanie środowiska wychowawczego [Understanding the Upbringing Environment]. Wydawnictwo PAN, Wrocław, 1960. (in Polish)

[15] Piotrowska M. Wpływ rozwodu rodziców na ich dorosłe dzieci. [Impact of Parents' Divorce Upon Their Adult Children]. Przegląd badań. Rocznik Andragogiczny, 2010. (in Polish)

[16] Przybyła-Basista H. Zmieniające się rodziny w zmieniającym się świecie a wyzwania dla współpracy rodzicielskiej [Changing Families in the Changing World and Challenges of Parental Cooperation]. Międzynarodowe Studia Społeczno-Humanistyczne Humanum, 2 (2017), 8. (in Polish)

[17] Rocznik demograficzny 2018 [Demographic Yearbook of Poland 2018]. Warszawa, 2018, 14. (in Polish)

[18] Sendyk M. Rodzina o zmienionej strukturze wewnętrznej jak źródło wykluczenia społecznego młodzieży [A Family with Changed Internal Structure as a Source of Youth's Social Exclusion]. "Rocznik lubuski", 3 (2013), 37. (in Polish)

[19] Sokal U. Wartości preferowane przez osoby dorosłe pochodzące z rodzin pełnych i rozwiedzionych [Values Preferred by Adults From Full and Divorced Families]. Roczniki Socjologii Rodziny, 13 (2001), 169-171. (in Polish)

[20] Sokołowska E. Dorosłe dzieci rozwiedzionych rodziców [Adult Children of Divorced Parents]. Ogrody Nauk i Sztuk, 3 (2013), 120. (in Polish)

[21] Sozańska E. Rodzina jako środowisko wychowania $w$ wartościach [Family as an Environment of Upbringing in Values]. Łódzkie Studia Teologiczne, 3 (2014), 41. (in Polish)

[22] Stachyra J. Wpływ rodziny na kształtowanie się osobowości dziecka [Influence of a Family Upon Formation of Child's Personality]. Sympozjum, 2 (2000), 88. (in Polish)

[23] Stosunek Polaków do rozwodów [Opinions of Poles on Divorce]. Komunikat z badań, 7 (2019), 5. (in Polish)

[24] Szczepanowska E., Ignaszewski J. Komentarz do spraw o rozwód, [Commentary on Divorce Cases]. Wydawnictwo Wolters Kluwer, Warszawa, 2016. Available at: https://static.profinfo.pl/. (in Polish)

[25] Szczepańska B. Ogólnopolskie badania jakości życia związanej ze zdrowiem fizycznym i psychicznym kobiet w wieku 45-60 lat [National Research on the Quality of Life Related to Physical and Mental Health of Women Aged 45-60]. Probl Hig Epidemiol, 4 (2009), 509. (in Polish)

[26] Szczepański J. Elementarne pojęcia socjologii [Elementary Concepts of Sociology]. Wydawnictwo PWN, Warszawa, 1979. (in Polish)

[27] Świętochowska K. Zachowania prospołeczne w organizacjach [Pro-Social Behaviours in Organisations]. Zeszyty Naukowe Politechniki Łódzkiej, 1203 (2015), 134. (in Polish)

[28] Tyszka Z. System metodologiczny wieloaspektowej integracji analizy życia rodzinnego [Methodological System of Multi-Faceted Integration of Family Life Analysis]. Wydawnictwo UAM, Poznań, 2001. (in Polish)

[29] Tyszka Z. Rodzina we wspótczesnym świecie [Contemporary World Family]. Wydawnictwo UAM, Poznań, 2002. (in Polish)

[30] Wojciechowska M. Spójność systemu wartości rodziców z systemem wartości ich dzieci [Coherence Between Parents' and Children's Systems of Values]. Wydawnictwo Stachurski, Kielce, 2008. (in Polish)

[31] Wojciechowska M. Wartości młodszego i starszego pokolenia Polaków w okresie transformacji ustrojowej [Values of Younger and Older Generation of Poles During the Political Transformation Period]. Wydawnictwo UJK, Kielce, 2008. (in Polish)

[32] Wojciechowska M. Wartości młodzieży i jej rodziców. W kręgu refleksji nad edukacja, [Values of Youth and Their Parents. Reflecting Upon Education]. Wydawnictwo UJK, Kielce, 2018. (in Polish)

[33] Woydyłło E. Elementarz współuzależnienia [Textbook of Co-dependence]. Arka, 39 (2002), 9. (in Polish)

[34] Ziemska M. Postawy rodzicielskie [Parental Attitudes]. Wydawnictwo Wiedza Powszechna, Warszawa, 1986. (in Polish)

[35] Ziółkowski P. Pedagogizacja Rodziców Potrzeby i Uwarunkowania [Parental Education - Requirements and Conditions]. Wydawnictwo Wyższej Szkoły Gospodarki w Bydgoszczy, Bydgoszcz, 2016. (in Polish) 
Address: Mariola Wojciechowska, Jan Kochanowski University, Faculty of Pedagogy and Psychology, 11 Krakowska St., Kielce 25-029, Poland, Marlena Michalska (a social worker), Poland.

E-mail: mariola.wojciechowska@vp.pl; marlenamichalska@interia.pl.

Received: 15.02.2021; revised: 18.03.2021.

Маріола Войчеховска, Марлена Міхалска. Функціонування дорослих із неповних сімей у родинному та професійному середовищі. Журнал Прикарпатського університету імені Василя Стефаника, 8 (1) (2021), $35-45$.

Сучасний світ ставить ведикі вимоги до людей, коли йдеться про розуміння його мети та значення, що, безсумнівно, змінюе життя людей та соціальних груп. Дюди особливо стурбовані можливістю звільнитися від нав'язаних групових зв'язків, користуватися правами громадянина та члена громади, а також способом реалізації свободи без обмежень. Те, що на сьогоднішній день будо добре встановленою основою дюдської діяльності та підтримання існуючого порядку, зараз втрачає своє значення і замінюється новими життєвими мождивостями. Авторитет традиційних соціальних структур, таких як: соціальний клас, місцева громада чи сім'я, знизився. Нормативна та аксіологічна системи, а отже, якість функціонування сучасної сім'ї, її структура, обсяг виконуваних обов'язків та відносини між їі членами також зазнали змін. Все частіше дорослі, які становлять головну вісь сім'ї, приймають рішення про розлучення. Це також не сприяє оптимальному розвитку дітей, оскільки вони втрачають почуття захищеності, довіри до дорослих, не реалізують власне життя і навіть сумніваються в існуванні справжньої безкорисливої любові. Рішення батьків про розлучення часто призводять до емоційних та мотиваційних розладів, які виявдяються у труднощах встановдення соціальних контактів, налагодженні гдибоких стосунків та вирішення складних ситуацій. У статті представлено результати досліджень щодо того, як дорослі, виховані в неповних сім'ях, можуть функціонувати в соціальному та професійному середовищі. Автори використовують метод діагностичного обстеження із використанням анкети для аудиторії та інструменту “100 речень - 100 думок" Мірослава Я. Шиманського. Результати дослідження чітко показують, що дорослі, які живуть в неповних сім'ях, по-різному беруть участь у соціальному та професійному житті. Вони будують свої коротко- та довгострокові професійні та особисті цілі різними способами. Особистісні та соціальні характеристики респондентів е факторами, що визначають спостережувану активність. Результати досліджень відповідають відповідній літературі та доводять впдив дорослішання в неповній родині на активність дітей у майбутньому.

Кдючові слова: неповна сім'я, розлучення, соціальна та професійна діяльність, родинне середовище. 